\title{
Taxonomic studies and three new records on genus Geostachys (Baker) Ridl. in Thailand
}

\author{
PIYAPORN SAENSOUK ${ }^{1}$, SURAPON SAENSOUK ${ }^{2, v}$ \\ ${ }^{1}$ Plant and Invertebrate Taxonomy and Its Applications Unit Group, Department of Biology, Faculty of Science, Mahasarakham University, \\ Kantarawichai District, Maha Sarakham, 44150, Thailand \\ 2Plant and Invertebrate Taxonomy and Its Applications Unit Group, Walai Rukhavej Botanical Research Institute, Mahasarakham University. \\ Kantarawichai District, Maha Sarakham, 44150, Thailand. "email: surapon.s@msu.ac.th
}

Manuscript received: 30 April 2021. Revision accepted: 30 June 2021

\begin{abstract}
Saensouk P, Saensouk S. 2021. Taxonomic studies and three new records on genus Geostachys (Baker) Ridl. in Thailand. Biodiversitas 22: 3057-3067. A comprehensive taxonomic study and three new records of genus Geostachys (Baker) Ridl. in Thailand have not been reported. This research aimed to study the taxonomical aspect of the genus Geostachys in Thailand based on herbarium collections, fresh materials, and available literatures. Nine species of Geostachys have been recognized with their updated nomenclature in Thailand, namely G. angustifolia K. Larsen, G. chayanii Mayoe, G. decurvata (Baker) Ridl., G. holttumii K. Larsen, G. kerrii K. Larsen, G. penangensis Ridl., G. pierreana Gagnep., G. smitinandii K. Larsen, and. G. tratensis Picheans. \& Mayoe. Three species, namely $G$. decurvata, G. pierreana, and G. penangensis are found to be new records to Thailand. Six species, namely $G$. angustifolia, $G$. chayanii, G. holttumii, G. kerrii, G. smitinandii, and G. tratensis were endemic to Thailand. The identification key to species, detailed descriptions, photographs, vernacular name, geographical distribution, ecology, phenology, conservation status, and taxonomic notes have been provided.
\end{abstract}

Keywords: Geostachys, taxonomy, Thailand, Zingiberaceae

Abbreviations: AUU: Herbarium, Science Museums, University of Aarhus, Denmark; BK: Bangkok Herbarium, Department of Agriculture, Thailand; BKF: The Forest Herbarium, National Parks, Wildlife and Plant Conservation Department, Thailand; C: Natural History Museum of Denmark; E: Herbarium, Royal Botanic Garden Edinburgh, Scotland; K: Herbarium, Royal Botanic Gardens, Kew, England; KYO: Kyoto University Herbarium; P: Herbier National, Muséum National d'Histoire Naturelle, Paris, France; PSU: Herbarium of Department of Biology, Prince of Songkla University, Thailand; QBG: Queen Sirikit Botanic Garden Herbarium, Thailand.

\section{INTRODUCTION}

The ginger family or Zingiberaceae is aromatic herbs, creeping horizontal or tuberous rhizomes with about 57 genera and a total of about 1,587 accepted species in the world (http://www.ipni.org;http://apps.kew.org/wcsp/). This family is distributed throughout tropical Africa, Asia, and the Americas, while Southeast Asia as the center of diversity for this family (Kress et al. 2007; LeongŠkorničková et al. 2019). Zingiberaceae in Thailand is reported more than 26 genera and over 300 species, and the numbers will most certainly rise (Boer et al. 2018). Geostachys (Baker) Ridl. is a plant genus in the family Zingiberaceae, subfamily Alpinioideae, and tribe Alpinieae (Kress et al. 2002). The genus is distributed mainly in Southeast Asia from Vietnam, Thailand, Sumatra, Peninsular Malaysia and Borneo, with its center of diversity in Peninsular Malaysia (Mabberley 1993; Larsen and Larsen 2006; Mayoe 2010). Geostachys is characterized by rhizomes with supported on stilt roots, short or fairly short inflorescence from the base of the leafy shoots, and the inflorescences erect, ascending, or decurved with flowers all pointed upwards (Mayoe 2010). All species of Geostachys has been found in the mountain at altitude 1,000-2,000 $\mathrm{m}$ asl. (Mayoe 2010). In general, the genus can be used for medicinal plants (Larsen and Larsen 2006; Mayoe 2010).

Baker (1892) introduced the name of Geostachys as a subgenus of Alpinia when he first described two species from Perak, namely Alpinia decurvata Baker and $A$. secunda Baker. Then, Ridley (1909) studied Geostachys from Malay Peninsula. Twenty-five species of Geostachys were recognized in worldwide (Lau and Lim 2012; https://wcsp.science.kew.org/namedetail.do?name_id=2469 35). Lau and Lim (2012) published revision of the genus Geostachys (Zingiberaceae) in Peninsular Malaysia. Later, Lau (2014) reported 15 species of Geostachys in Peninsular Malaysia with key to species, conservation measures, and including 13 endemic species, 4 Endangered species, 8 Vulnerable species, and 1 Near Threatened species.

In Thailand, Larsen (1996) published the checklist of Thai Zingiberaceae including four Geostachys species. Then, Larsen and Larsen (2006) reported five species, i.e. Geostachys kerrii K. Larsen, G. holttumii K. Larsen, $G$ angustifolia K. Larsen, G. smitinandii K. Larsen, and $G$. decurvata (Baker) Ridl. inThailand. Later, Mayoe (2010) reported a new species, Geostachys chayanii Mayoein Southern Thailand. Moreover, Forest Botany Division 
(2014) reported seven species of the genus Geostachys, namely $G$ angustifolia, $G$. chayanii, $G$. decurvata, $G$. holttumii, G. kerrii, G. smitinandii and $G$. tratensis Picheans, but a comprehensive taxonomic study of Geostachys in Thailand has not been reported. Therefore, this research aimed to study the taxonomical aspect of the genus Geostachys in Thailand based on herbarium collections, fresh materials, and available literature.

\section{MATERIALS AND METHODS}

\section{Plant materials}

Some plant materials were collected from field trips in Thailand, pressed and fixed in $70 \%$ alcohol during field trips between 2017 to 2020. Some voucher specimens were deposited at the Mahasarakham University Herbarium. Themorphological characters (leaf, leaf-sheath, inflorescence, bract, bracteole, flower, calyx, corolla lobe, labellum, lateral staminode, stamen, stigma, ovary) of the plant materials were studied under stereo microscopy. Protologues and other relevant taxonomic literature were searched and referred to typifications. The morphological descriptions were based on a detailed study of the collected specimens from the field and herbarium specimens deposited in the following herbaria: AAU, C, BK, BKF, E, K, KYO, P, PSU, QBG (Figures 1 and 2).

\section{Procedures}

The data presented here, including plant measurements indicated in description of the studied species were obtained mainly from herbarium specimens. Plant diversity, vernacular names, distribution data and ecological data were taken from the field, herbarium specimens, and available literature. All species are described based on specimens from the field and herbarium specimens. Identification key is constructed from detailed descriptions. The traditional utilization data was taken from interviews with local people near the site locality of each species, herbarium specimens, and available taxonomic literature.

\section{RESULTS AND DISCUSSION}

\section{Taxonomy of Geostachys}

Nine species of Geostachys have been recognized with their updated nomenclature, namely Geostachys angustifolia K. Larsen, G. chayanii Mayoe, G. decurvata (Baker) Ridl., G. holttumii K. Larsen, G. kerrii K. Larsen, G. penangensis Ridl., G. pierreana Gagnep., G. smitinandii K. Larsen and. G. tratensis Picheans. \& Mayoe. Three species, namely $G$. decurvata, $G$. pierreana and $G$. penangensis are found to be new records to Thailand. Six species, namely G. angustifolia, G. chayanii,G. holttumii, $G$. kerrii, G. smitinandii and G. tratensis were endemic to Thailand.

\section{Taxonomic treatment of Geostachys}

Ridley, J. Straits Branch Roy. Asiat. Soc. 32:157 (1899); Gagnepain, Fl. Indo-Chine 6(1):100 (1908); Holttum, Gard. Bull. Singapore 13:224 (1950); Larsen, Bot. Tidsskr. 58: 43-49 (1962); Larsen, Lock, Maas \& Maas, Fam. Gen. Vasc. Pl. 4:494 (1998); Leong-Škorničková \& Newman, Gingers of Cambodia, Laos and Vietnam:149 (2015); Lau, Lim \& Mat-Salleh, Garden' Bulletin Singapore 59 (1\&2): 129-138 (2007); Lau \& Lim, Folia Malaysiana13: 7-42 (2012); Lau, Gardens' Bulletin Singapore 66(1): 3-14 (2014). - Alpinia Subgen. Geostachys Baker, Fl. Brit. India 6:257 (1892) — Carenophila Ridl. Ridley, J. Fed. Malay States Mus. 4(1):78 (1909).

\section{General characteristic of Geostachys in Thailand}

Medium-sized herbs to $3 \mathrm{~m}$ tall with many leafy shoots close together from a rhizome raised above the ground on numerous stilt roots. Leaves narrowly lanceolate, cuspidate. Inflorescence on a separate shoot from rhizome with short peduncle covered with stiff, often red sheaths; rachis erect or recurved. Bracts loosely overlapping leaving rachis visible. Flowers borne evenly around rachis or secund and pointing upwards, yellow or straw-colored, often with red stripes or blotches; labellum commonly trilobed and slightly longer than corolla lobes. Fruit oblong to oblong-obovate or ellipsoid or orbicular, 1.1-1.7 $\mathrm{cm} \times 0.5-1.9 \mathrm{~cm}$, green when young or turning reddishbrown when mature or shining maroon or red or light pink in young and reddish when mature, glabrous, crowned by persistent calyx or not seen. Seeds 2-11 in each locule, oblong or obovate or ovate to oblong, 5-7 $\times 3-5 \mathrm{~mm}$, white with small thread-like aril or not seen.

\section{Key to the species of Geostachys in Thailand}

1. Labellum yellowish or cream .................................. 2

1. Labellum pink ........................................ 8

2. Inflorescence with deflexed rachis ........................ 3

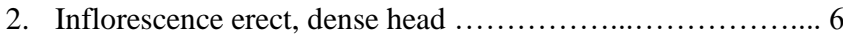

3. Rachis of inflorescence not over $7 \mathrm{~cm}$. long ................. 4

3. Rachis of inflorescence much longer on well-grown plants ...5

4. Bracteoles inflated-tubular, pseudostem $35-79 \mathrm{~cm}$ tall

.......................................................... G. penangensis

4. Bracteoles spath, pseudostem $80-100 \mathrm{~cm}$ tall ..... G. pierreana

5. Inflorescence lax, rachis glabrous ................ G. decurvata

5. Inflorescence dense, rachis hairy .................... kerrii

6. Labellum yellowish or cream with red spots and a dark red veins at the base; a yellow band in the middle ...............7

6. Labellum yellowish or cream without red spots; a yellow veins in the middle .................................. G. chayanii

7. Leaves blade firmly chartaceous, slightly to moderately plicate; linear-elliptic to elliptic ................... G. holttumii

7. Leaves blades not firmly chartaceous; lanceolate-oblong or elliptic .......................................... G. angustifolia

8. Petiole $0.5-1.2 \mathrm{~cm}$ long; ligules 4-7 $\times 5-6 \mathrm{~mm}$, apex bilobed, hairy, greenish; leaves blade lanceolate, upper surface glabrous, lower surface hairy; involucral bract hairy ..... G. smitinandii

8. Petiole 3-4.5 cm long; ligules 8-10 × 7-8 mm, apex acute, glabrous, red; leaves blade oblong, glabrous on both sides; involucral bract glabrous G. tratensis 

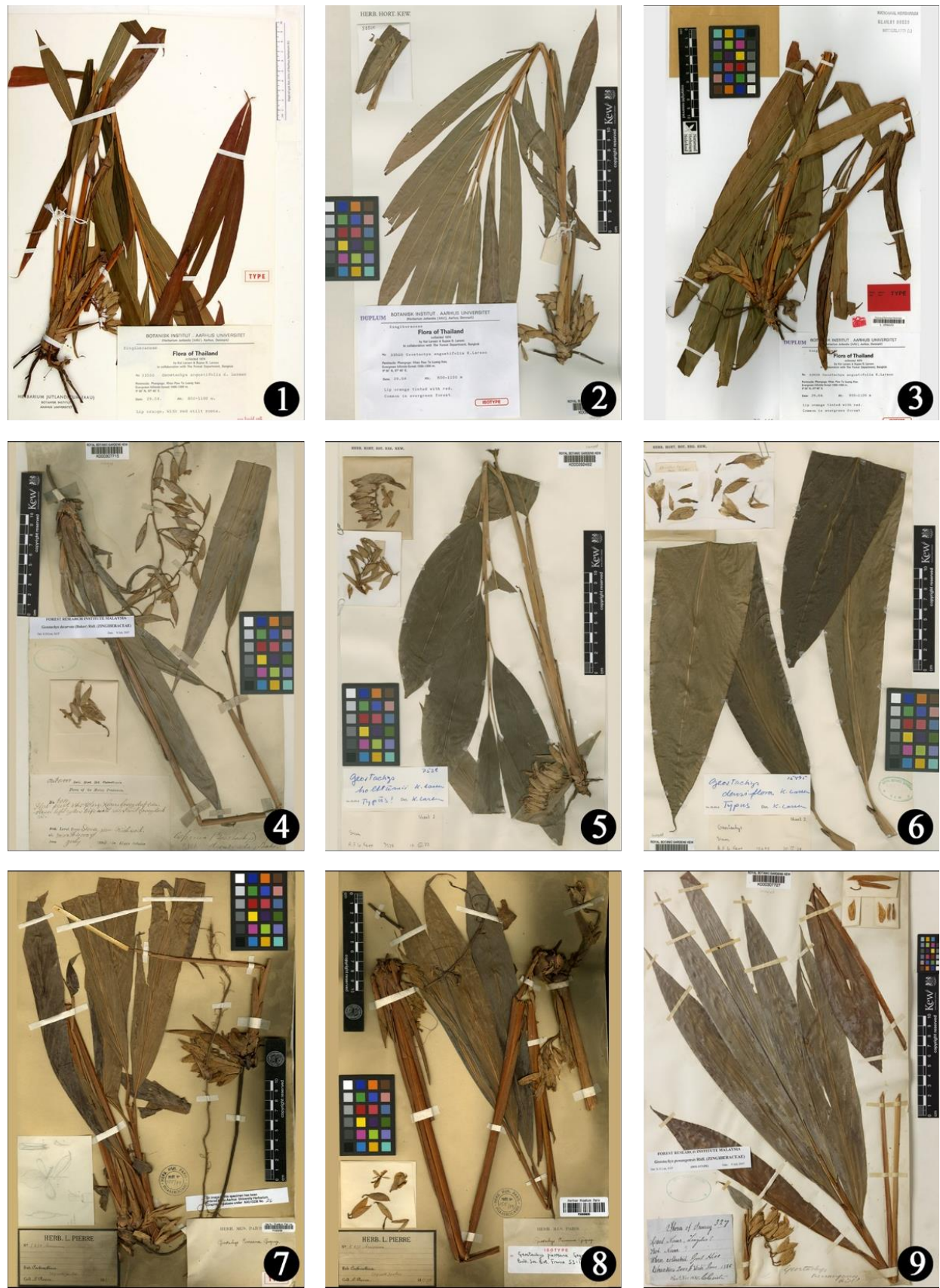

Figure 1. Plant materials of Geostachysin Thailand. 1. Holoype of Geostachys angustifolia K. Larsen (Thailand, Phangnga, Larsen, K. \& Larsen, S.S. 33500, 29.04.1974(AAU)), 2. Isotype of G. angustifolia K. Larsen (Thailand, Phangnga, Larsen, K. \& Larsen, S.S. 33500, 29.04.1974, K000292493(K)), 3. Isotype of G. angustifolia K. Larsen (Thailand, Phangnga, Larsen, K. \& Larsen, S.S. 33500 , 29.04.1974, L0596353(L)), 4. G. decurvata(Baker) Ridl. (Malaysia, Perak, King 6310, 07.1884, K000307715 (K)), 5. G. holttumiiK. Larsen (Thailand, Yala Province, Kerr 7538, 10.08.1923, K000292492 (K)), 6. G. kerrii K. Larsen (Thailand, Nakhon Si Thammarat, Kerr 15495, 30.04.1928, K000292490 (K)), 7. Holotype of G. pierreana Gagnep. (Laos, L. Pierre 5851, 1865-1877, P032698 (MNHN)), 8. Isootype of G. pierreana Gagnep. (Laos, L. Pierre 5851, 1865-1877, P00686635 (MNHN)), and 9. Holotype of G. penangensisRidl. (Malaysia, Penang, C. Curtis 327, 06.1885, K000307727 (K)).

Note: Link of photographs of Type specimen (access available online: 1 July 2021)

(1) https://www.aubot.dk/show_image.php?CatalogNumber=K.Larsen33500\&RecID=3913\&imgType=specimenImg

(2) http://apps.kew.org/herbcat/getImage.do?imageBarcode=K000292493

(3)https://proxy.europeana.eu/11656/Botany_L_0596353?view=http\%3A\%2F\%2Fmedialib.naturalis.nl\%2Ffile\%2Fid\%2FL0596353_

MLN\%2Fformat\%2Flarge\&disposition=inline\&api url=https\%3A\%2F\%2Fapi.europeana.eu\%2Fapi

(4) http://specimens.kew.org/herbarium/K000307715

(5) http://apps.kew.org/herbcat/getImage.do?imageBarcode=K000292492

(6) http://specimens.kew.org/herbarium/K000292490

(7) http://mediaphoto.mnhn.fr/media/14435466457873VyQijo8As1EZ1Zh

(8) http://mediaphoto.mnhn.fr/media/1443546379324IDH8qhitXVhlvnkj

(9) http://specimens.kew.org/herbarium/K000307727 

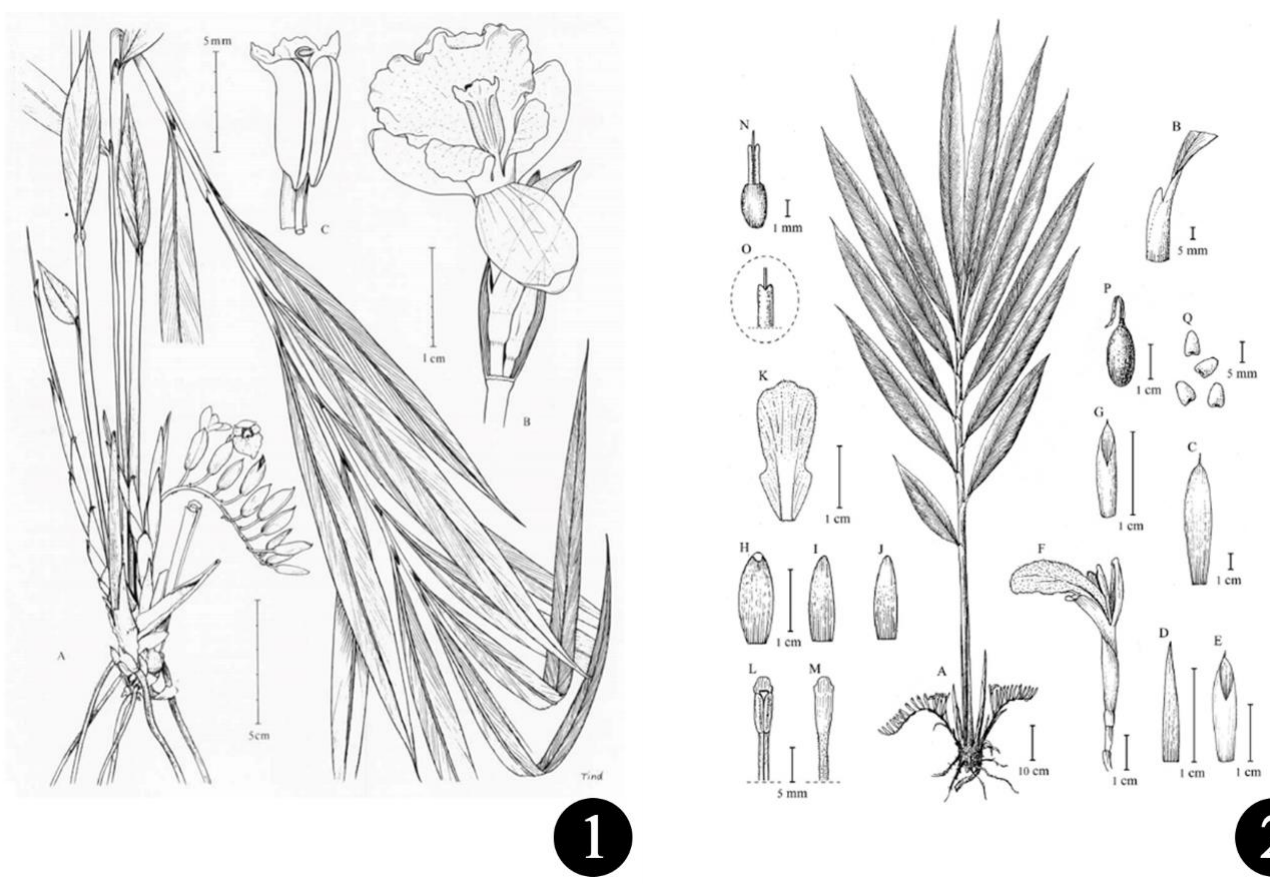

1

2
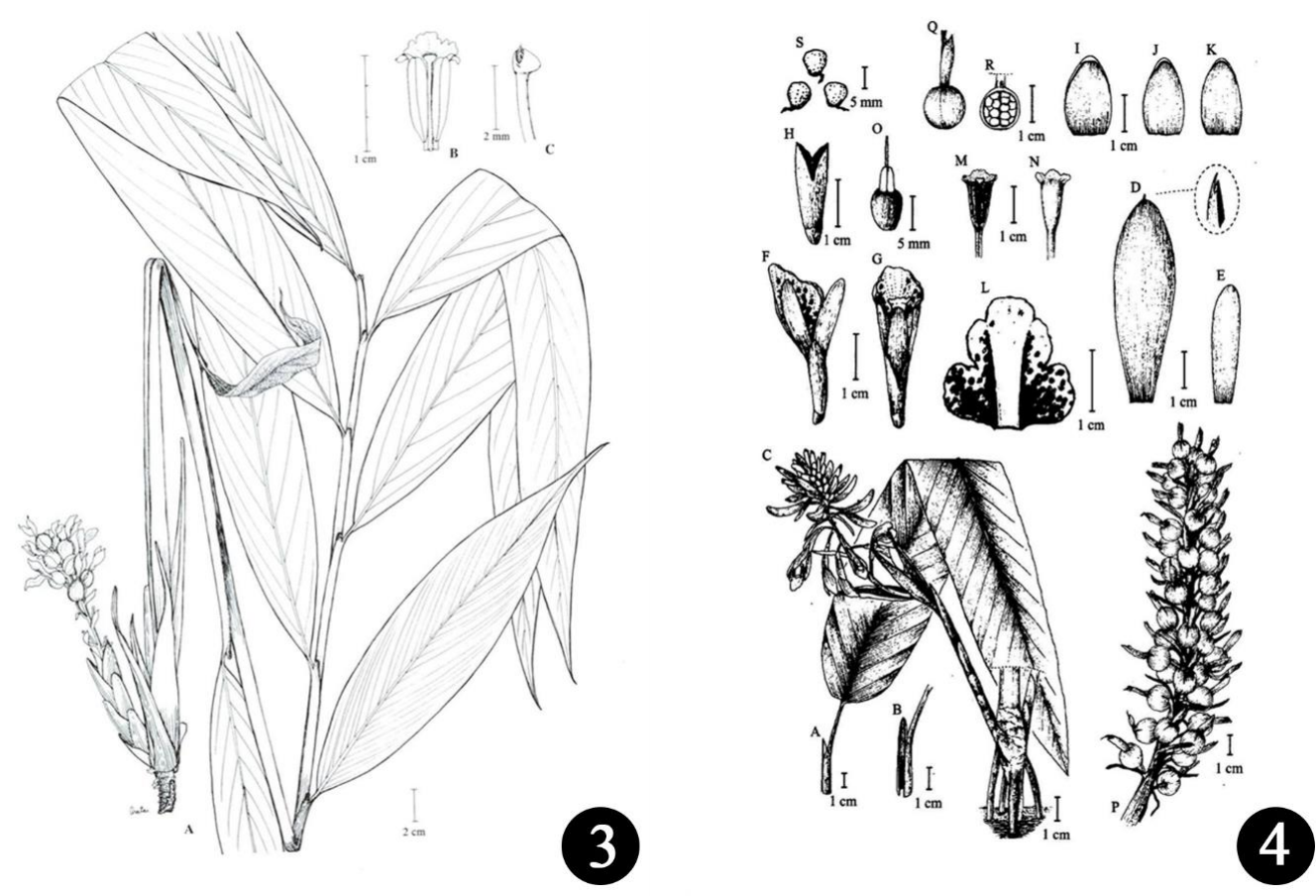

Figure 2. Plant illustrations from first publication of four species of Geostachys in Thailand. 1. Geostachys angustifolia K. Larsen (Larsen 1986), 2. G. chayanii Mayoe (Mayoe 2010), 3. G. smitinandii K. Larsen (Larsen 2001), and 4. G. tratensis Picheans. \& Mayoe (Picheans. \& Mayoe 2011)

Geostachys angustifolia K. Larsen, K. Larsen in Nordic Journal of Botany,6: 31-33.1986; Type: Larsen, K.; Larsen, S.S., \#33500 (holotype AAU!, isotypes K!, BKF!).

Perennial herb, $30-35 \mathrm{~cm}$ tall. Rhizome creeping, slender, bearing pseudostems at intervals. Leaf-sheaths 1 , normal leaves 2; ligules 1-2 mm, apex bilobed, glabescent. Leaves: blade lanceolate-oblong or elliptic, 20-30 × 5-10 $\mathrm{cm}$, base attenuate, apex acuminate or mucronate, margin entire to slightly undulate, both sides glabrous, upper surface dark green, lower surface lighter green; petioles 9$12 \mathrm{~cm}$, glabrous, green, channeled. Inflorescences arising from rhizome between bases of pseudostems, with flowers in an erect, dense head; peduncle $0.6-1.2 \mathrm{~cm}$; bracts $6-8$, lanceolate, light pinkish, ca $2 \times 0.7 \mathrm{~cm}$; bracteoles lanceolate, $1.5 \times 3.5 \mathrm{~mm}$. Flower: calyx $2.7-3 \mathrm{~cm}$, usually longer than floral tube, pinkish to reddish-white with yellowish apex; corolla tube yellowish, dorsal lobe oblong, ca $1.8 \times 1.0 \mathrm{~cm}$, pinkish to reddish, hooded, lateral 
lobes oblong, ca $1.8 \times 7 \mathrm{~mm}$, pinkish to reddish, slightly hooded; lateral staminodes absent; labellum suborbicular, ca $2.5 \times 2 \mathrm{~cm}$, pale yellow with a dark red band at base and a yellow band in the middle, hairy towards throat; base clawed, 5-8 $\mathrm{mm}$; veins dark red; distal part trilobed, median lobe crenate, sometimes slightly emarginate; stamen: filament short, ca $5 \times 3 \mathrm{~mm}$, yellowish; anther ca $4 \times 3 \mathrm{~mm}$; anther-crest, whitish, ca $3 \times 2 \mathrm{~mm}$, apex obtuse, ovary $2-5 \times 2-4 \mathrm{~mm}$, pubescent; style filiform, 2.3-3 cm long, glabrous; stigma triangular with ciliate apex, inconspicuous; epigynous gland 2, slender, apex shallowly emarginate. Fruit and seed not seen.

Vernacular names:- Rew Phu

Distribution.- It is distributed only in Southern Thailand: Phangnga province at Khao Paw Ta Luang Keo (Figure 3). Therefore, it is reported to be endemic to Thailand.

Ecology.- It is growing common in evergreen forest at an elevation of 100-1000 $\mathrm{m}$ asl.

Phenology.- Flowering from March to June.

Conservation status.- This species is reported in IUCN Red List categories as Data Deficient (DD) (Oleander 2019a). The species is currently known few areas and small populations. This species is here proposed as being Endangered (EN) and rare species.

Specimens examined. - Nakhon Srithamarat, Khao Luang: Larsen, K. \& Larsen, S.S. \#33500 (AAU, K, BKF) ; same location, C.F.van Beusekam \& C. Phengkhlai 786 (BKF, K, P, E, C, AAU, KYO).

Note.-The species has distinctive labellum orange tinted with red. The morphological characters of $G$. angustifolia are similar to those of $G$. chayanii, but it differs in its dark red veins in parts of the labellum.

Geostachys chayanii MayoeTaiwania, 55(1): 8-12, 2010. -Type: Picheansoonthon 1021 (holotype BKF!, isotypes BK!, SING!)

Perennial rhizomatous herb up to $160 \mathrm{~m}$ tall. Rhizome raised above ground on stilt roots. Leaf-sheaths 3-4 basal, brown. Leaves 9-14, arranged in upper part of pseudostem; blade oblong-lanceolate, 30.1-37.2 × 2.3-4.7 $\mathrm{cm}$, tapering towards petiole, apex acuminate, margin undulate, glabrous on both sides; ligule oblong, 6-7 mm long, green or greenish-brown, glabrous, apex acute; petiole $1.7-2.1 \mathrm{~cm}$ long. Inflorescences $11.1-14.7 \mathrm{~cm}$ long, glabrous, slender; peduncle $2.3-4.7 \mathrm{~cm}$ long, glabrous, lower part covered with $6-10$ reddish sheaths, oblong, 1.1-1.4 × $0.8-1.1 \mathrm{~cm}$ long, apex obtuse or acute, upper part covered with 2-3 dry and membranous involucral bracts, oblong, $6.1-7.6 \times 1.2-1.5 \mathrm{~cm}$, apex mucronate, increasing in length upwards, basal part of inflorescence ascending, upper part decurved; rachis glabrous; cincinni stalk $0.7-1.1 \mathrm{~cm}$ long;flowers only in the part extending from the involucral bracts; primary bracts subtending the cincinni oblong, $1.1-1.7 \times$ ca $0.3 \mathrm{~cm}$, apex acute, membranous, cauduous; bracteoles tubular, 1.5$2 \times 0.5-0.7 \mathrm{~cm}$, split ca $5 \mathrm{~mm}$, apex mucronate, glabrous; pedicel ca4 mm long, glabrous. Flower; calyx 1.2-1.4 $\times$ $0.4-0.55 \mathrm{~cm}$, split ca $0.3 \mathrm{~cm}$ on one side, apex mucronate; corolla tube ca $1.1 \mathrm{~cm}$ long; dorsal lobe ovate, $1.4-1.5 \times$ ca $0.7 \mathrm{~cm}$, apex hooded, basal part light reddish, upper part light cream color; lateral lobes oblong, 1.4-1.5 × 0.5-0.6 $\mathrm{cm}$, apex obtuse to slightly hooded, basal part light reddish, upper part light cream color; labellum oblong-obovate, $1.9-2 \times 1.2-1.3 \mathrm{~cm}$, lateral staminodes two, small ca 0.5 $\times 0.3 \mathrm{~mm}$, minutely hairy on upper surface; stamen: filament ca $8 \mathrm{~mm}$ long, hairy abaxially; anther ca $6 \times 2$ $\mathrm{mm}$, opening by longitudinal slits; anther crest ca $2 \mathrm{~mm}$ long and wide, concave, apex round or acute, with or without two small side lobes: ovary oblong, ca $3 \times 1.5-2$ $\mathrm{mm}$, glabrous; style filiform, up to $3 \mathrm{~cm}$ long, glabrous; stigma obconical, ostiole horizontal; epigynous gland 1, apex shallowly emarginate. Fruit oblong to oblongobovate, $1.4-1.5 \mathrm{~cm} \times 5-7 \mathrm{~mm}$, turning reddish-brown when mature. Seeds 2 in each locule, obovate, ca $6 \times 4 \mathrm{~mm}$, white with small thread-like aril.

Vernacular names:- Rew Phu

Distribution. - It is discovered endemic to Nakhon Si Thammarat province, Peninsular Thailand (Figure 3).

Ecology.- It grows in evergreen hillside forest on humus soil, on rock under the shades, at the altitude of 890 $1200 \mathrm{~m}$ asl.

Phenology.-Flowering May. Fruits from June to October.

Conservation status. - This species is reported in IUCN Red List categories as Endangered (EN) (Oleander $2019 b$ ). The species is currently known only from the type locality area. This species is here proposed as being Endangered (EN) and rare species.

Specimens examined. - Nakhon Srithamarat, Khao Luang, Beusekom \& Phengklai 786 (BKF); same location, Kerr 15438 (BK); same location, Picheansoonthon 1027 (BKF); Nakhon Si Thammarat, Khao Maen, Picheansoonthon 1056 (BKF).

Note.- The species has distinctive labellum orange tinted with red. The morphological characters of $G$. chayanii are similar to those of $G$. angustifolia, but it differs in its dark red veins in parts of the labellum. Moreover, both taxa are quite different when observing all details of the fruits- $G$. angustifolia has the reddish-brown subglobose fruits which turn black when matured, while $G$. chayanii has the green obovate-oblong fruits which turn reddish-brown when matured.

Geostachys holttumii K. Larsen K. Larsen, Bot. Tidsskr. 58: 47. 1962; Thai Forest Bull. Bot., 24: 42. 1996. - Type: Betong, A.F.G. Kerr 7538 (holotype K!).

Perennial rhizomatous herb $35-70 \mathrm{~cm}$ tall. Rhizome short, stout, woody, 5-7 $\mathrm{mm}$ in diam., slightly above or at ground level, supported by stilt roots; leafy shoots with 5-9 leaves. Leaf-sheaths 3-4 basal, brown. Leaves petiolate; sheaths green, longitudinally ribbed when dry, glabrous; ligule 7-15 mm long, apex acute or obtuse, margin glabrous to ciliate; blade linear-elliptic to elliptic, $7.5-30.5 \times 1-8 \mathrm{~cm}$, firmly chartaceous, slightly to moderately plicate, yellowish-green to dark green, glabrous, base cuneate, apex acuminate, margin entire or slightly undulate, midrib grooved above, prominent underneath; petiole to $3 \mathrm{~cm}$ long, glabrous. Inflorescences arising from rhizome at base of leafy shoot, 11-15.5 cm long, 1-2 flowers open at a time; peduncle 
erect, slightly curved, $4.5-8.5 \mathrm{~cm}$ long, sparsely puberulent to subglabrous; peduncular bracts clasping, appressed, imbricate, concave, triangular-ovate to oblong, brown, glabrous, apex rounded to acute, margin ciliate or glabrous (especially in uppermost bract), uppermost bract to ca $7 \times$ $1.5 \mathrm{~cm}$; rachis decurved, with 10-13 cincinni, 4-6 cm long, green, reddish or pinkish cream, sparsely puberulent; bracts clasping, appressed, membranous, 1-3(-10) $\mathrm{mm}$ long, yellowish-brown, outer surface sparsely puberulent to subglabrous, apex rounded or obtuse, rarely acute or acuminate, margin ciliate; bracteole inflated-tubular, outer ones $2-3.8 \mathrm{~cm}$ long, chartaceous, split to halfway down, yellowish-brown, glabrous, apex acuminate. Flowers 1-3 per cincinnus; pedicels $2-5 \mathrm{~mm}$ long; calyx $1.8-2 \mathrm{~cm}$ long, membranous, yellowish, hooded, split half-way down, glabrous, 7-9-nerved, apex acuminate; corolla tube 1.7$1.9 \mathrm{~cm}$ long, cream or yellowish, glabrous, corolla lobes oblong, membranous, dorsal lobe $13-17 \times 6-8 \mathrm{~mm}$, 5- or 7-nerved, apex hooded, obtuse or rounded, lateral lobes 12-15 × 4-6 mm, 3- or 5- nerved, apex slightly hooded, obtuse or rounded; labellum trilobed, yellowish cream with red spots, central lobe obovate, $2-2.1 \times 1.3-1.6 \mathrm{~cm}$, apex bifid and curved downward, margin slightly crumpled and recurved, adaxial surface puberulent, abaxial surface glabrous, lateral lobes spreading or slightly erect, ligulate to subtriangular or nearly semi-orbicular, 7-8 $\mathrm{mm}$ long, adaxial surface puberulent in basal part, glabrous distally and abaxially, apex rounded to subacute or sometimes emarginate, margin often slightly recurved; stamen: filament flattened, 4-7 mm long, puberulent; anther oblong, 7-8 × 2-2.5 mm, yellowish cream, puberulent on thecae; anther crest ca $1 \mathrm{~mm}$ long, apex rounded, with reddish blotch, margin sparsely ciliate to glabrous; ovary ca $3 \mathrm{~mm}$ long, outer surface glabrous; ovules many per locule; style filiform, 2.7-3.2 cm long, glabrous; stigma cup-shaped, obconical, ca $1 \mathrm{~mm}$ in diam., yellowish cream, ostiole transverse, elliptic in outline, with ciliate margin; epigynous glands usually comprising 2 fleshy masses, sometimes connate into a single mass (split to base on one side only), 2-3 mm long, glabrous, apex rounded to subacute, subentire to slightly irregularly lobed;. Fruit capsule ellipsoid, red, glabrous, crowned by persistent calyx. Seeds 2 in each locule, obovate, ca $7 \times 5 \mathrm{~mm}$, white with small thread-like aril.

Vernacular.- Pud

Distribution. - It is found to be endemic to Thailand and it is discovered only in the south, Yala province (Betong district) (Figure 3).

Ecology.- It grows on the humus soils or sandy heath soils over the rockyof evergreen forest, at the altitude of 650-700 m asl.

Phenology.- Flowering from May to June. Fruits June.

Conservation status.- This species is reported in IUCN Red List categories as Data Deficient (DD) (Oleander 2019d). The species is currently known only from the type locality area. This species is here proposed as being Endangered $(\mathrm{EN})$ and rare species.

Specimens examined.- Yala, Betong, A.F.G. Kerr 7538 (K000292492); same locality, J. Wai 773 (BKF, PSU), 800 (PSU).
Note.- The type specimen of this species (A.F.G. Kerr 7358) was collected from Betong, the type locality, Thailand.

Geostachys kerrii K. Larsen, Notes Roy. Bot. Gard. Edinburgh 31(2): 241 (1972) — Geostachys densiflora K. Larsen later homonym, Bot. Tidsskr. 58: 45 (1962) Type: Gunung Kerbau, H.C. Robinson s.n. (20 March 1913) (holotype K!).

Perennial rhizomatous herb up to $35 \mathrm{~cm}$ tall. Rhizome raised on stilt roots, creeping, slender, bearing pseudostems at intervals. Leaf-sheaths 1, normal leaves 10; ligule 1-2 mm long, apex bilobed, glabrous; Leaves blade elliptic, $18-30 \times 5-10 \mathrm{~cm}$, base attenuate, apex acuminate or mucronate, margin entire to slightly undulate, both sides glabrous, upper surface dark green, lower surface lighter green; petioles up to $12 \mathrm{~cm}$, glabrous, green, channeled. Inflorescences arising from rhizome between bases of pseudostems, decurved; peduncles $0.5-1 \mathrm{~cm}$; bracts 6-8, lanceolate, ca $1.8 \times 0.8 \mathrm{~cm}$, light pink; bracteoles lanceolate, $1.6 \times 3.5 \mathrm{~mm}$. Flower: calyx $2.5-3$ $\mathrm{cm}$, usually longer than floral tube, pinkish to reddish white with yellowish apex, corolla lobes yellowish, dorsal lobe oblong, ca $1.8 \times 1.0 \mathrm{~cm}$, pinkish to reddish, hooded; lateral lobes oblong, ca $1.8 \times 7 \mathrm{~mm}$, pinkish to reddish, slightly hooded; labellum suborbicular, ca $2.5 \times 2.0 \mathrm{~cm}$, yellow, base clawed, 5-8 mm, veins dark red, trilobed distally, median lobe crenate, sometimes slightly emarginate; lateral staminodes absent; stamen: filament short, ca $5 \times$ $3 \mathrm{~mm}$, yellowish; anther ca $4 \times 3 \mathrm{~mm}$, anther-crest absent; ovary $2-5 \times 2-4 \mathrm{~mm}$, pubescent; style filiform, $1.5-1.7 \mathrm{~cm}$ long, glabrous; stigma triangular with ciliate apex, inconspicuous; epigynous glands 2, slender, 5-6 $\times$ ca $1 \mathrm{~mm}$, not surrounding style. Fruit and seed not seen.

Vernacular names:- - Pud

Distribution.- - It is recorded to be endemic to Thailand and it is discovered only in the south, Phangnga province (Figure 3).

Ecology.- This species is found in evergreen forest, at the altitude of 100-1000 m asl.

Phenology.- Flowering from March to May. Fruits from May to June.

Conservation status. - This species is reported in IUCN Red List categories as Least Concern (LC) (Oleander 2019e). The species is currently known only from the type locality area. This species is here proposed as being Endangered $(\mathrm{EN})$ and rare species.

Specimens examined.- Penang, R. Geesink \& $T$. Santisuk 5150 (BKF).

Note.-The cultivated plants are found taller than wild plants.

Geostachys smitinandii K. Larsen, Thai For. Bull. (Bot.), 29: 17-22 (2001).— Type: Larsen, Smitinand \& Warncke 55 (holotype AAU!, isotype BKF!, fruiting specimens).

Perennial rhizomatous herb up to $1.6 \mathrm{~m}$ tall. Rhizome raised above ground on stilt roots. Leaf-sheaths 3-4, basal, brown. Leaves 9-14, arranged in upper part of pseudostem; blade oblong-lanceolate, 30.1-37.2 × 2.3-4.7 $\mathrm{cm}$, tapering towards petiole, apex acuminate, margin 
undulate, glabrous on both sides; ligule oblong, 6-7 mm long, green or greenish-brown, glabrous, apex acute; petiole $1.7-2.1 \mathrm{~cm}$ long. Inflorescences $1-\mathrm{few}$ at base of pseudostem, 11.1-14.7 cm long, glabrous, slender; peduncle $2.3-4.7 \mathrm{~cm}$ long, glabrous, lower part covered with $6-10$ oblong, reddish sheaths, $1.1-1.4 \times 0.8-1.1 \mathrm{~cm}$, apex obtuse or acute, upper part covered with $2-3$ oblong, dry and membranous involucral bracts, $6.1-7.6 \times 1.2-1.5$ $\mathrm{cm}$, apex mucronate, increasing in length upwards, basal part of inflorescence ascending, upper part decurved (rarely ascending); rachis glabrous; cincinni 16-21, uniflorous (rarely biflorous), pointing upward; cincinnus stalk 0.7-1.1 cm long; bracts subtending cincinni oblong, $1.1-1.7 \mathrm{~cm} \times$ ca $3 \mathrm{~mm}$, apex acute, membranous, cauduous; bracteoles tubular, $1.5-2 \times 0.5-0.7 \mathrm{~cm}$, split ca $0.3 \mathrm{~cm}$, apex mucronate, glabrous. Flower: pedicel $3-4 \mathrm{~mm}$ long, glabrous; calyx $1.2-1.4 \times 0.4-0.5 \mathrm{~cm}$, split ca $0.3 \mathrm{~cm}$ on one side, apex mucronate; corolla tube ca $1.1 \mathrm{~cm}$ long, dorsal corolla lobe ovate, $1.4-1.5 \times$ ca $0.7 \mathrm{~cm}$, apex hooded, basal part light reddish, upper part light cream, lateral corolla lobes oblong, $1.4-1.5 \times 0.5-0.6 \mathrm{~cm}$, apex obtuse to slightly hooded, basal part light reddish, upper part light cream; labellum oblong-obovate, 1.9-2 $\times 1.2-1.3$ $\mathrm{cm}$, with two small lateral lobes, minutely hairy on upper surface; lateral staminode absent; stamen: filament 7-8 $\mathrm{mm}$ long, dorsal part hairy, anther ca $6 \times 2 \mathrm{~mm}$, opening by longitudinal slits; anther crest ca $2 \mathrm{~mm}$ long and wide, concave, apex round or acute, with or without two small side lobes; ovary oblong, ca $3 \times 1.5-2 \mathrm{~mm}$, glabrous; style filiform, up to $2 \mathrm{~cm}$ long, glabrous; stigma obconical, ostiole horizontal at apex; epigynous gland 1, apex shallowly emarginate. Fruit oblong to oblong-obovate, $1.4-1.5 \times 0.5-0.7 \mathrm{~cm}$, green when young, turning reddishbrown when mature. Seeds 2 per locule, obovate, ca 6 $\times 4 \mathrm{~mm}$, white with small thread-like aril at base.

Vernacular.- Pud-Ajarn Tem

Distribution. - It is reported as endemic to Thailand. It is found in Nakhon Ratchasima province (EASTERN floristic region in Thailand) and Phetchaburi province located in south-western (floristic region in Thailand) (Figure 3).

Ecology.- It grows in dry evergreen forest on humus soil, on rock under the shades, at the altitude of 800-1200 masl (Figure 2).

Phenology. - Flowering in April to June, fruiting in June-July.

Conservation status. - This species is reported in IUCN Red List categories as Vulnerable (VU) (Chadburn et al. 2013).

The species is currently known few natural populations. This species is here proposed as being Endangered (EN) and rare species.

Specimens examined. - Khao Yai (Khao Khiao), Smitinand \& Warncke 55 (AAU, BKF); same location, J. Vidal, Y. Vidal \& C. Niyomdham 6375 (BKF, AAU, P); same location, P. Phonsena5916 (BKF, QBG) ; same location, J.F. Maxwell 00-408 (BKF, CMU); Phet Chaburi (Kaeng Kra Chan, P. Phongsena 5050 (BKF) ); same location, P. Phonsena, de Wilde, W.J.J..O \& Duyfjes, B.E.E. 6009 (BKF, BK, L) ; same location, P. Pongsena \& D.
Chusithong 5951 (BKF); Chantaburi, P. Pongsena, D. Chusithong \& W. Chausook 6135 (BKF); Saensouk s.n. (Mahasarakham University Herbarium); Kanchanaburi, Sangklaburi, C.F. van Beusekom \& C. Phengklai 347 (BKF, K, P)

Note.- Inflorescence and flowers are found beautiful pink color.

Geostachys tratensis Picheans. \& Mayoe, Jpn. Bot. 86(3): 133-138 (2011). — Type: Thailand, Trat, C.Picheansoonthon \& J. Mayoe 020510-1 (holotype BKF!, BK, isotype SING!).

Perennial rhizomatous herb up to $3.1 \mathrm{~m}$ high. Rhizome supported above ground level by thick stilt roots, bearing pseudostems at intervals. Leaf-sheaths reddish, bladeless sheaths $2-4$. Ligule oblong, $0.8-1 \mathrm{~cm} \times 7-8 \mathrm{~mm}$, apex acute, glabrous, red. Leaves petioles $3-4.5 \mathrm{~cm}$ long, red; blade blong, 32.9-49.7 × 7-8.7 cm, base oblique to round, apex acute to acuminate, margin entire or slightly undulate, both surfaces glabrous. Inflorescences 2-5 at base of the pseudostem, erect or slightly drooping, 10.4$21.4 \mathrm{~cm}$ long; peduncle $4.7-17 \mathrm{~cm}$ long, glabrous, lower part of the axis without flower, covered with involucral bracts; involucral bracts $9-18$, the uppermost one the largest, obovate to oblong, 7.3-10 × 1.7-2.7 cm, apex acute or mucronate, pinkish-red, glabrous; bract lanceolate to oblong, $2.1-4.5 \times 0.8-1.1 \mathrm{~cm}$, apex acute, glabrous, white to pinkish-white; cincinnae uniflorous spreading evenly on all sides. Flowers white with red-spotted; calyx tubular, 1.4-1.6 cm × 4-6 mm, apex 2-dentate, split one side, whitish; corolla tube slightly shorter than calyx tube, 1.2$1.4 \mathrm{~cm} \times$ ca. $3 \mathrm{~mm}$, 3-lobed, lobes linear, apex hooded, white, $1.5-2.1 \mathrm{~cm} \times 5-8 \mathrm{~mm}$; labellum spreading, triangular, whitish with red-spotted at base and along the margin, 3.1-3.6 × 2-2.5 cm, pubescent; stamen: filament red, $0.7-1.2 \mathrm{~cm}$ long, pubescent; anther dorsifixed, opening by longitudinal slits, $0.9-1.2 \mathrm{~cm} \times 3-5 \mathrm{~mm}$; ovary oblong or globose, 3-5 × 2-5 mm, 3-loculed, placentation axile, glabrous; style filiform, up to $2.5 \mathrm{~cm}$ long, glabrous; stigma red, densely ciliate; epigynous glands 2, surrounding style, ca. $2 \times 2 \mathrm{~mm}$, yellowish. Fruits orbicular, $1.2-1.7 \times 1.2-1.9 \mathrm{~cm}$, glabrous, light pink in young and reddish when mature, pedicel $0.6-1.7 \mathrm{~cm}$ long, calyx persistent, $1.4-1.9 \mathrm{~cm} \times 3-4 \mathrm{~mm}$. Seeds $5-11$ in locule, ovate to oblong, ca. $5 \times 3-4 \mathrm{~mm}$, white.

Vernacular names:-Krawan Daeng

Distribution.- It is reported as endemic species to Thailand. This species is so far known from the type locality, Khao Buntad-Khao Kuap (Thailand, Trat province) in the mountain range bordering Thailand and Cambodia (Figure 3).

Ecology. - It grows in disturbed evergreen forest at the altitude 730-780 $\mathrm{m}$ asl. The type area is near the ThailandCambodia border, previously a military camp of the former Khmer Rouge, and still full of landmines.

Phenology. - Flowering from end of March to early May; fruiting from April to June.

Conservation status. - This species should beData Deficient (DD) (Oleander 2019g). The species is currently 
known only from the type locality area. This species is here proposed as being Endangered (EN) and rare species.

Specimens examined.-Trat, Picheansoonthon \& Mayoe 230509-1 (BK, BKF, SING).

Note.-This species is related to G. smitinandii K. Larsen but differs in its much longer petioles (3-4.5 cm vs. $0.5-1.2 \mathrm{~cm})$, red ligules with acute apices, much longer bracts $(2.1-4.5 \mathrm{~cm}$ vs. $1-1.3 \mathrm{~cm})$, and glabrous involucral bracts.

\section{Three new records from Thailand}

Geostachys decurvata (Baker) Ridl., J. Straits Branch Roy. Asiat. Soc. 32:158 (1899) -Alpinia decurvata Baker, Fl. Brit. India 6: 257 (1892). - Type: Robinson, H.C., \#s.n., K!; Geostachys decurvata (Baker) Ridl., J. Straits Branch Roy. Asiat. Soc. 32: 158 (1899). -Alpinia decurvata Baker, Fl. Brit. India 6: 257 (1892). - Type: Perak, H.H. Kunstler 6310 (holotype K!, isotypes P!, SING!).

Perennial rhizomatous herb up to $240 \mathrm{~cm}$ tall. Rhizome supported above ground level by thick stilt roots, bearing pseudostems at intervals. Leafless sheath 1 . Leaves 5-6; ligule ca $3 \mathrm{~mm}$ long, apex bilobed, glabrescent; blade lanceolate-oblong or elliptic, 50-68×5$9 \mathrm{~cm}$, base attenuate, apex acuminate or mucronate, margin entire to slightly undulate, both sides glabrous, upper surface dark green, lower surface lighter green or reddish; petiole $12-13 \mathrm{~cm}$, glabrous, green, channeled. Inflorescence arising from rhizome between bases of pseudostems, decurved, flowers conspicuously secund; peduncle $0.6-1.2 \mathrm{~cm}$ long; bracts $6-8$, lanceolate, ca $2 \times$ $0.7 \mathrm{~cm}$ light pink; bracteoles lanceolate, $1.5 \times 3.5 \mathrm{~mm}$. Flower: calyx $2.7-3 \mathrm{~cm}$, usually longer than corolla tube, pinkish to reddish-white with yellowish apex; corolla lobes yellowish, dorsal lobe oblong, $1.8-1.9 \times 1-1.1 \mathrm{~cm}$, pinkish to reddish, hooded, lateral lobes oblong, ca $1.8 \times 0.7 \mathrm{~cm}$, pinkish to reddish, slightly hooded; labellum suborbicular, ca $2.5 \times 2 \mathrm{~cm}$, trilobed distally, median lobe round and broad, side lobes round, yellow with occasional small red spots, hairy towards throat; lateral staminodes absent; stamen: filament short, ca $5 \times 3 \mathrm{~mm}$, yellowish; anther ca $4 \times 3 \mathrm{~mm}$; anther crest ca $3 \times 2 \mathrm{~mm}$, whitish, apex obtuse; ovary 2-5 × 2-4 mm, pubescent; style filiform, $2.4-2.9 \mathrm{~cm}$ long, glabrous; stigma triangular with ciliate apex, inconspicuous; epigynous glands 2 , slender, 5-6 6 ca 1 $\mathrm{mm}$, not surrounding style. Fruit ellipsoid, glabrous, shining maroon. Seeds ca 6 in locule, oblong, ca. $5.5 \times 4$ mm, white.

Vernacular names:- Pud

Distribution. - It is distributed in Peninsular Thailand (Nakhon Si Thammarat province) (Figure 3) and Malay Peninsula

Ecology. - This is discovered in evergreen forest at an elevation of 100-1000 m asl.

Phenology. - Flowering from April to June. Fruits June to October.

Conservation status. - This species is reported in IUCN Red List categories as Endangered (CR) (Oleander 2019c). The species is currently known only from Yala province. This species is here proposed as being Endangered (EN) and rare species.
Specimens examined. - Yala, Hala Bala: M., Poopath 357 (BKF).

Note.- The first described as Alpinia decurvaya by J.G. Baker in 1892 then transferred to Geostachys as $G$. decurvata in 1899 by H.N. Ridley, therefore A. decurvaya Baker, became the synonym of Geostachys decurvata (Baker) Ridl. Its native range is Peninsula Malaysia (Gunung Hijau) according to http://www.plantsoftheworldonline.org/ (KewScience. 2021). It is placed in new record for Thailand.

Geostachys pierreana Gagnep., Bull. Soc. Bot. France 53: 147 (1906). - Type: Thailand, Chantaburi, Pierre 5851 (holotype P!).

Perennial rhizomatous herb, $80-100 \mathrm{~cm}$ tall. Rhizome short, stout, woody, to $7 \mathrm{~mm}$ in diam, slightly above or at ground level, supported by stilt long roots. Leaf-sheaths 3, green-brown. Leaves 2-9 leaves, petiole ca $10 \mathrm{~mm}$ long, hirsuta, sheath green, glabrous; ligule ca 3 $\mathrm{mm}$ long, triangular, apex obtuse, margin glabrous to ciliate; blade lanceolate-linear, 28-30× 4-5 cm, firmly chartaceous, slightly to moderately plicate, yellowish-green to dark green, glabrous, base attenuate, apex long acuminate, margin entire or slightly undulate, midrib grooved above with pubescence, prominent below with pubescence; petiole. Inflorescences arising from rhizome at base of leafy shoot, up to $10 \mathrm{~cm}$ long, 1-2 flowers open at a time; peduncle erect, decurved, up to $8 \mathrm{~cm}$ long, sparsely puberulent to subglabrous; peduncular bracts clasping, appressed, imbricate, concave, triangular, brown, pubescent, apex acuminate, margin glabrous, uppermost bract to ca $7 \times 1 \mathrm{~cm}$; rachis decurved, with 8-10 cincinni, up to $6 \mathrm{~cm}$ long, green, reddish or pinkish cream, puberulent; bracts clasping, appressed, 1-3 mm long, membranous, yellowish, outer surface sparsely puberulent, apex acute, margin ciliate; cincinni all secund, erect, bearing 3-4 flowers, stalks 5-10 $\mathrm{mm}$ long, green or pinkish cream, sparsely puberulent; bracteoles spath, outer ones 28-30 mm long, chartaceous, brown, ciliate, apex acuminate. Flower: pedicel upto $9 \mathrm{~mm}$ long;calyx tubular, 1.2-1.5 cm long, 7-9-nerved, membranous, brownish, hooded, split to near base, ciliate, apex acuminate; corolla yellowish, ciliate, corolla tube 1.7-2 $\mathrm{cm}$ long, corolla lobes membranous, oblong, dorsal lobe 15-17 $\times$ 7-8 mm, 5- or 7-nerved, apex hooded, obtuse or rounded, lateral lobes $13-15 \times 5-6 \mathrm{~mm}, 3$ - or 5- nerved, apex slightly hooded, obtuse or rounded; labellum ovate, trilobed, concave, yellowish cream with red spots, lateral lobes spreading or slightly erect, ligulate to subtriangular or nearly semi-orbicular, 7-8 mm long, inner surface puberulent at base, glabrous apically, outer surface glabrous, apex rounded to subacute or sometimes emarginate, margin often slightly recurved, central lobe obovate, 2-2.1 $\times 1.3-1.6 \mathrm{~cm}$, apex bifid and curved downward, margin slightly crumpled and recurved, inner surface puberulent, outer surface glabrous; lateral staminodes absent; stamen: filament flattened, ca $7 \mathrm{~mm}$ long, puberulent; anther oblong, ca $8 \times 2-2.3 \mathrm{~mm}$, yellowish cream, puberulent on pollen sacs; anther crest ca $1.5 \mathrm{~mm}$ long, apex rounded, with reddish blotch, margin 
sparsely ciliate; ovary ca $3 \mathrm{~mm}$ long, outer surface glabrous; ovules many per locule; style filiform, ca $3.3 \mathrm{~cm}$ long, glabrous; stigma cup-shaped, ca $1 \mathrm{~mm}$ in diam., obconical, yellowish cream, ostiole transverse, elliptic in outline, with ciliate margin; epigynous glands usually comprising 2 fleshy masses, sometimes connate into a single mass (only split to base on one side), ca $3 \mathrm{~mm}$ long, glabrous, apex rounded to subacute, subentire to slightly irregularly lobed. Fruit ellipsoid, ca $10 \mathrm{~mm}$ long, ca $6 \mathrm{~mm}$ wide, red, glabrous, crowned by persistent calyx. Seeds not seen.

Vernacular names:- Pud

Distribution.- - It is found in eastern part of Thailand at Chanthaburi province (Khao Khitchakut) (Figure 3), Cambodia and maybe in Vietnam.

Ecology.- It grows in montane evergreen forest at altitude 900-1000 $\mathrm{m}$ asl.

Phenology.- Flowering from April to June. Fruits June to October.

Conservation status. - This species is reported in IUCN Red List categories as Data Deficient (DD) (Oleander 2019f). The species is currently known only from Chanthaburi province (Khao Khitchakut). This species is here proposed as being Endangered (EN) and rare species.

Specimens examined.- Chantaburi, Khao Khitchakut, Nai Noe 77 (BK, P).

Note. - The collecting locality in Cambodia and date of the type specimen, Pierre 5851 (P) are not known.

While, the only first Thai collection known is Nai Noe 77 (BK, P) which he collected in 1925 on Khao Khitchakut.Therefore, it is a new record for Thailand.

Geostachys penangensis Ridl., J. Straits Branch Roy. Asiat. Soc. 32: 159. 1899; Ridl., Mat. Fl. Malay. Penins. 2: 45. 1907; Fl. Malay. Penin. 4: 276. 1924; R.M. Sm., Notes Roy. Bot. Gard. Edinburgh 43(3): 463. 1986. - Type: Peninsular Malaysia Penang; Govt Hill,Curtis, C., \#327 (holotype K!).

Perennial rhizomatous herb, up to $70 \mathrm{~cm}$ tall. Rhizome short, stout, woody, 5-7 $\mathrm{mm}$ in diam, slightly above or at ground level, supported by stilt roots. Leafy shoots with 5-9 leaves; base 1-1.3 cm in diam.; leaves petiolate; sheath green, longitudinally ribbed when dry, glabrous; ligule 7-15 mm long, apex acute or obtuse, margin glabrous to ciliate; blade linear-elliptic to elliptic, $7.5-30.5 \times 1-8 \mathrm{~cm}$, firmly chartaceous, slightly to moderately plicate, yellowish-green to dark green, glabrous, base cuneate, apex acuminate, margin entire or slightly undulate, midrib grooved above, prominent below; petiole to $3 \mathrm{~cm}$ long, glabrous. Inflorescences arising from rhizome at base of leafy shoot, 11-15.5 cm long, 1-2 flowers open at a time; peduncle erect, slightly curved, 4.5-8.5 cm long, sparsely puberulent to subglabrous; peduncular bracts clasping, appressed, imbricate, concave, triangular-ovate to oblong, brown, glabrous, apex rounded to acute, margin ciliate or glabrous (especially in uppermost bract), uppermost bract to ca $7 \times 1.5 \mathrm{~cm}$; rachis decurved, with 10-13 cincinni, 4-6 cm long, green, reddish or pinkish cream, sparsely puberulent; bracts clasping, appressed, 1-3(-10) mm long, membranous, yellowish brown, outer surface sparsely puberulent to subglabrous, apex rounded or obtuse, rarely acute or acuminate, margin ciliate; cincinni all secund, erect, bearing 1-3 flowers, stalks 5-15 mm long, green or pinkish cream, sparsely puberulent; bracteoles inflated-tubular, outer ones 2-3.8 $\mathrm{cm}$ long, chartaceous, yellowish brown, glabrous, split to halfway, apex acuminate. Flower: pedicel 2-5 mm long; calyx 1.8-2 cm long, 7-9-nerved, membranous, yellowish, hooded, split half-way down, glabrous, apex acuminate; corolla lobes cream or yellowish, glabrous, corolla tube $1.7-1.9 \mathrm{~cm}$ long, corolla lobes membranous, oblong, dorsal lobe 13-17 × 6-8 mm, 5- or 7-nerved, apex hooded, obtuse or rounded, lateral lobes $12-15 \times 4-6 \mathrm{~mm}, 3$ - or 5- nerved, apex slightly hooded, obtuse or rounded; labellum trilobed, yellowish cream with red spots, lateral lobes spreading or slightly erect, ligulate to subtriangular or nearly semiorbicular, 7-8 mm long, inner surface puberulent at base, glabrous apically, outer surface glabrous, apex rounded to subacute or sometimes emarginate, margin often slightly recurved, central lobe obovate, 2-2.1 × 1.3-1.6 cm, apex bifid and curved downward, margin slightly crumpled and recurved, inner surface puberulent, outer surface glabrous; lateral staminodes absent; stamen: filament flattened, 4-7 mm long, puberulent; anther oblong, 7-8 × 2-2.5 mm, yellowish cream, puberulent on pollen sacs; anther crest ca $1 \mathrm{~mm}$ long, apex rounded, with reddish blotch, margin sparsely ciliate to glabrous; ovary ca $3 \mathrm{~mm}$ long, outer surface glabrous; ovules many per locule; style filiform, 2.7-3.2 cm long, glabrous; stigma cup-shaped, ca $1 \mathrm{~mm}$ in diam., obconical, yellowish cream, ostiole transverse, elliptic in outline, with ciliate margin; epigynous glands usually comprising 2 fleshy masses, sometimes connate into a single mass (only split to base on one side), 2-3 mm long, glabrous, apex rounded to subacute, subentire to slightly irregularly lobed. Fruit ellipsoid, red, glabrous, crowned by persistent calyx. Seeds not seen.

Vernacular. - Pud

Distribution. - It is distributed in Peninsular Thailand (Yala province, Betong district) (Figure 3), Peninsular Malaysia and Borneo.

Ecology.- It grows decaying leaf litter or on thin rocky or sandy heath soils over rock on evergreen forest, at altitude 650-700 $\mathrm{m}$ asl.

Phenology. - Flowering in May-August, fruiting in July-October.

Conservation status.-This species is reported in IUCN Red List categories as Endangered (EN) (Oleander and Lau 2019). The species is currently known only from Yala province, Betong district. This species is here proposed as being Endangered (EN) and rare species.

Specimens examined.- Yala, Betong, J. Wai 218 (PSU), 240 (BKF, PSU), 309 (PSU).

Note.- Its former native range is Peninsula Malaysia (Pulau Pinang). Recently, it is collected from Betong district, Yala province, Thailand. Therefore, it is reported to be a new record for Thailand. 


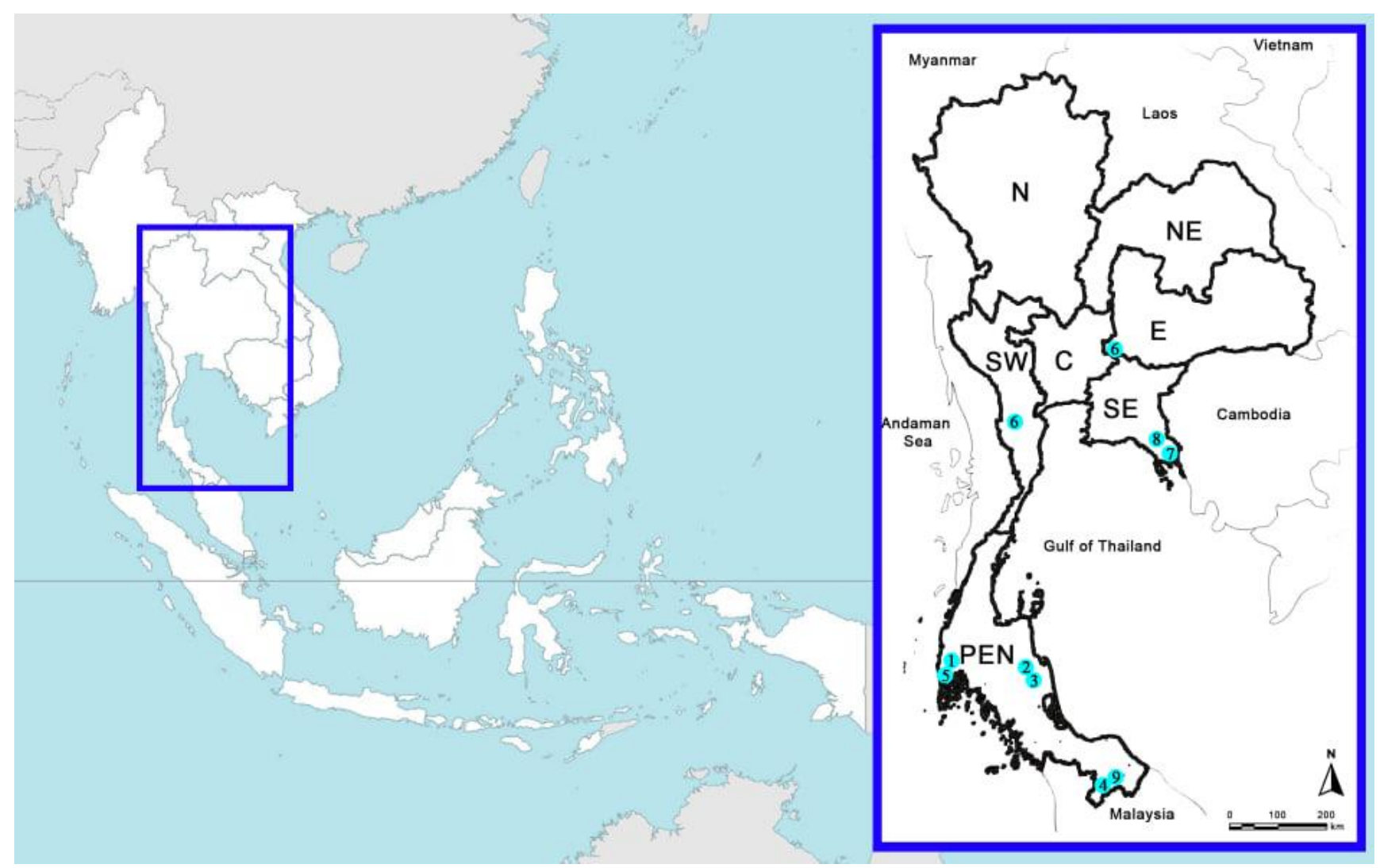

Figure 3. Map of Thailand with neighbor countries showing the distribution of nine species of Geostachysfrom Thailand. 1. Geostachys angustifolia K. Larsen, 2. G. chayanii Mayoe, 3. G. decurvata Baker. Ridl., 4. G. holttumii K. Larsen, 5. G. kerrii K.Larsen, 6. G. smitinandii K. Larsen, 7. G. tratensis Picheans. \& Mayoe, 8. G. pierreana Gagnep., and 9. G. penangensis Ridl. Phytogeographical areas of Thailand as used in the Flora of Thailand project. Provincial borders are indicated. N: Northern, NE: North-eastern, E: Eastern, SW: South-western, C: Central, SE: South-eastern, PEN: Peninsular (SEA map source: https://aseanup.com/wpcontent/uploads/2015/04/ASEAN-map-white-blank.jpg)

In conclusion, taxonomic study of the genus Geostachys in Thailand is reported nine species, namely Geostachys angustifolia, G. chayanii, G. decurvata, G. holttumii, G. kerrii, G. penangensis, G. pierreana, G. smitinandii and. G. tratensis. Three species, i.e. G. decurvata, G. pierreana and G. penangensis have been found to be new records to Thailand. Key to species ofGeostachys in Thailand is constructed base on dominant characteristics i.e. which is the height of the pseudostem, characters of leaf blade, length of petiole, apex and size of ligule, inflorescence, rachis of inflorescence, surface of involucral bract, shape of bracteole and labellum.

\section{ACKNOWLEDGEMENTS}

We indebted Dr. Mark Newman, the specialist in Zingiberaceae for his kind to improve and correct our manuscript. Many thanks to Thawatphong Boonma for his help with some data. We would like to thank the Walai Rukhavej Botanical Research Institute, Mahasarakham University for their facilities during the research. This research was financially supported by Mahasarakham University.

\section{REFERENCES}

Baker JG.1892. Scitamineae. In: Flora of British India. Hooker, f. (ed.), vol. 6, pp. 252-257. L. Reeve, Kent, London.

Chadburn H, Contu S, Romand-Monnier F. 2013. Geostachys smitinandii. The IUCN Red List of Threatened Species 2013: e.T44393080A44541780. DOI: 10.2305/IUCN.UK.20132.RLTS.T44393080A44541780.en.

Forest Botany Division. 2014. Thai Plant Names Tem Smitinand. Forest and Plant Conservation Research Office, Department of National Parks, Wildlife and Plant Conservation, Bangkok.

Gagnepain F. 1908. Zingibéracéae. In:Flore Générale L’Indo-Chine. Lecomte H (ed.), vol. 6, pp. 85-100. Masson, Paris. [French]

Holttum RE. 1950. The Zingiberaceae of the Malay Peninsula.The Gard Bull Sing 13 (1): 1-249.

KewScience. 2021. World checklist of selected plant families (WCSP). http://apps.kew.org/wcsp/

Kress WJ, Prince LM, Williams JK. 2002. The phylogeny and a new classification of the gingers (Zingiberaceae): evidence from molecular data. Amer J Bot 89 (11): 1682-1696.

Larsen K, Larsen SS. 2006. Gingers of Thailand. Queen Sirikit Botanic Garden, Chiang Mai, Thailand.

Larsen K, Lock JM, Maas H, Maas PJM. 1998. Zingiberaceae. In: Kurbitzki K (ed.). The Families and Genera of Vascular Plants. Springer-Verlag, London.

Larsen K. 1962. Studies in Zingiberaceae. I. The genus Geostachys in Thailand. Bot Tidsskr 58: 43-49.

Larsen K. 1996. A preliminary checklist of the Zingiberaceae of Thailand. Thai For Bull (Bot) 24: 35-49. 
Larsen K. 2001. Geostachys smitinandii K. Larsen (Zingiberaceae), a new species from Thailand. Thai For Bull 29: 17-22.

Larsen, K. 1972. Studies in the genus Globba in Thailand-Appendix. Notes R Bot Gard Edin 31: 241.

Lau KH, Lim CK, Mat-Salleh K. 2007.Materials for a Taxonomic Revision of Geostachys (Baker) Ridl. (Zingiberaceae) in Peninsular Malaysia. Gard Bull Sing 59 (1\&2): 129-138.

Lau KH, Lim CK. 2012. Revision of the genus Geostachys (Zingiberaceae) in Peninsular Malaysia. Folia Malaysiana 13: 7-42.

Lau KH. 2014. The conservation of Peninsular Malaysian Geostachys (Zingiberaceae). Gard Bull Sing 66 (1): 3-14

Leong-Škorničková J, Newman M. 2015. Gingers of Cambodia, Laos and Vietnam. Singapore.

Mabberley DJ. 1993. The Plant Book: A Portable Dictionary of the Higher Plants. Cambridge University Press, London.

Mayoe J. 2010. A new species of Geostachys Ridl. (Zingiberaceae) from Southern Thailand. Taiwania 55 (1): 8-12.

Olander SB, Lau KH. 2019. Geostachys penangensis. The IUCN Red List of Threatened Species 2019: e.T117327581A124282557. DOI: 10.2305/IUCN.UK.2019-2.RLTS.T117327581A124282557.en.

Olander SB. 2019a. Geostachys angustifolia. The IUCN Red List of Threatened Species 2019: e.T117326936A124282487. DOI: 10.2305/IUCN.UK.2019-2.RLTS.T117326936A124282487.en.

Olander SB. 2019b. Geostachys chayanii. The IUCN Red List of Threatened Species 2019: e.T117326936A124282487. DOI: 10.2305/IUCN.UK.2019-2.RLTS.T117326936A124282487.en.
Olander SB. 2019c. Geostachys decurvata. The IUCN Red List of Threatened Species 2019: e.T117327111A124282507. DOI: 10.2305/IUCN.UK.2019-2.RLTS.T117327111A124282507.en.

Olander SB. 2019d. Geostachys holttumii. The IUCN Red List of Threatened Species 2019: e.T117327226A124282527. DOI: 10.2305/IUCN.UK.2019-2.RLTS.T117327226A124282527.en.

Olander SB. 2019e. Geostachys kerrii. The IUCN Red List of Threatened Species 2019: e.T117327264A124282532. DOI: 10.2305/IUCN.UK.2019-2.RLTS.T117327264A124282532.en.

Olander SB. 2019f. Geostachys pierreana. The IUCN Red List of Threatened Species 2019: e.T117327601A124282562. DOI: 10.2305/IUCN.UK.2019-2.RLTS.T117327601A124282562.en.

Olander SB. 2019g. Geostachys tratensis. The IUCN Red List of Threatened Species 2019: e.T117327790A124282602. DOI: 10.2305/IUCN.UK.2019-2.RLTS.T117327790A124282602.en.

Picheansoonthon C, Mayoe J. 2011. Geostachys tratensis (Zingiberaceae): a new Species from Eastern Thailand. J Jpn Bot 86 (3): 133-138.

Ridley HN. 1899. The Scitamineae of the Malay Peninsula. J Str Br R Asiat Soc 85-184.

Ridley HN. 1907. Zingiberaceae. Materials for a Flora of the Malay Peninsula.The Methodist Publishing House, Singapore.

Ridley HN. 1909. The Flora of the Telom and Batang Padang Valleys. Journal of the Federated Malay States Museums 4 (1): 1-78.

Ridley HN. 1924. The Flora of the Malay Peninsula. L Reeve, London.

Smith RM. 1986. A review of Bornean Zingiberaceae: II (Alpineae, Concluded). Notes from the Royal Botanic Garden, Edinburgh 43 (3): 439-466. 